\title{
An Overview of Four Proposed Indicators of Active Learning to Improve English Teaching and Learning in Saudi Arabia
}

\author{
Oqab Alrashidi (Corresponding author) \\ School of Education, University of New England, Armidale, NSW, Australia \\ Tel: 612-6773-3949Ｅ-mail: oalrashi@myune.edu.au \\ Huy P. Phan \\ School of Education, University of New England, Armidale, NSW, Australia \\ Bing H. Ngu \\ School of Education, University of New England, Armidale, NSW, Australia
}

Received: June 10, 2016 Accepted: June 29, 2016 Published: July 3, 2016

doi:10.5296/ijele.v4i2.9696 URL: http://dx.doi.org/10.5296/ijele.v4i2.9696

\begin{abstract}
English is taught as a foreign language in schools and universities of Saudi Arabia. In recent years, officials and educationists have expressed their concerns pertaining to students' low levels of English achievement. To improve English learning and achievement in Saudi Arabia, many research studies have shown that four major indicators of active learning, namely: (a) group work, (b) elaborated feedback, (c) situated learning, and (d) Information Communication Technology [ICT], impact on students' leaning and successful achievement. This article provides an overview of these four indicators of active learning and their importance to English learning and teaching. In addition, the article sheds light on how these four indicators of active learning might be used by teachers and educators in their teaching practices and/or intervention programs.
\end{abstract}

Keywords: EFL in Saudi Arabia, group work, elaborated feedback, situated learning, ICT 


\section{The Saudi Context: The Learning of English Status Quo}

English is the only foreign language taught in schools and universities of Saudi Arabia (Alrashidi \& Phan, 2015). Students start learning English from the fourth grade of elementary stage up to tertiary education. In recent years, the Saudi Arabian government and educators have expressed serious concerns about the low level of proficiency in English among Saudi students (Alrashidi \& Phan, 2015; Khan, 2011; Ur Rahman \& Alhaisoni, 2013). While the government of Saudi Arabia applied great effort to improve English teaching and learning, standards of achievement in English among students in schools and universities are unsatisfactory and far below expectations (Alrashidi \& Phan, 2015; Al-Seghayer, 2014; Khan, 2011). Researchers (e.g., Alrashidi \& Phan, 2015; Alhawsawi, 2013; Rajab, 2013) have argued that, although Saudi students study English for nine years in public education (from the $4^{\text {th }}$ grade through $12^{\text {th }}$ grade) and about four years in higher education, most of them graduate with a very low competence in English.

A number of recent research studies (e.g., Alrashidi \& Phan, 2015; Al-Seghayer, 2014; Khan, 2011) have discussed and detailed the main reasons behind students' low performance in English language in contemporary Saudi Arabia. These reasons include the teacher-centred rather than student-centred English teaching and learning, teachers' reliance on the use of Arabic to teach the English language, students' dependence on memorization as the main learning strategy, the lack of a social target environment in which students can practice the English language, and students' lack of motivation and encouragement from their teachers (Alrashidi \& Phan, 2015). These issues, according to Alrashidi and Phan (2015), have contributed to students' low competence in English. Therefore, the need for improvement in students' proficiency in English is imperative to enable students, and the country in general, to maximise their benefits from learning English (e.g., the role English plays in the Saudi economy).

To improve English learning and teaching in Saudi Arabia, many research studies (e.g., Long \& Porter, 1985; Lave \& Wenger, 1991; Hattie \& Timperly, 2007) have shown that four major indicators of active learning, namely: (a) group work, (b) elaborated feedback, (c) situated learning, and (d) ICT, impact on students' learning and successful achievement. This article provides an overview about each of these four indicators of active learning with a focus on their importance to students' English learning. In addition, the article sheds light on how these four indicators of active learning might be used by teachers and educators in their teaching practices and/or intervention programs.

\section{The Four Indicators of Active Learning}

Active learning is an important means to enhance students' learning experiences (Prince, 2004; Dengler, 2008). Researchers (e.g., Bonwell \& Eison, 1991; Faust \& Paulson, 1998; Prince, 2004) have generally defined active learning as any instructional method that engages students to take part in meaningful learning tasks, and encourages them to think about the tasks they are doing. The key factors of active learning are students' activity and active involvement in the process of learning (Prince, 2004). Active learning has typically contradicted the traditional teacher-centred approach, where the latter approach emphasizes 
on students as being passive recipients of knowledge from instructors (Prince, 2004; Bell \& Kozlowski, 2008; Dengler, 2008). Previous research (e.g., Braxton, Milem, \& Sullivan, 2000; Dengler, 2008; Bell \& Kozlowski, 2008; Sivan, Leung, Woon, \& Kember, 2000) has suggested and examined numerous techniques/indicators of active learning including, for example, role playing, cooperative learning, peer teaching, computer-based instruction, and group work. The current research article discusses the aforementioned indicators of active learning (i.e., [a] group work, [b] elaborated feedback, [c] situated learning, and [d] ICT), which can be used to improve Saudi students' English learning. The following subsections provide an overview about the four selected indicators of active learning, and how they might be used by teachers and educators in their teaching practices and/or educational interventions to enhance students' English learning in Saudi Arabia.

\subsection{Group Work}

The use of group work in teaching English as a foreign language has been recognized to be an effective teaching strategy in the development of students' proficiency in English (Chen \& Hird, 2006; Ewald, 2004; Naughton, 2006). This teaching strategy has become increasingly paramount to provide students with the maximum language skills development through mutual support in groups and authentic peer interactions (Long \& Porter, 1985). As a result, researchers have asserted that the use of this strategy is important in providing students with possibilities to experience meaningful language learning and in allowing them to practice the language in an authentic, safe, and supportive environment (Brown, 2001; Long \& Porter, 1985; Long, 1996).

Although group work as a teaching strategy has been widely implemented and researched in Western settings, it is important for teachers and educators to apply this strategy in Saudi Arabia, where teacher-centred instruction dominates education at all levels (Ahmed, 2014; Alrashidi \& Phan, 2015; Alrabai, 2014). Brown (2001) and Ellis (1994) argued that traditional teacher-centred classrooms can only produce passive and teacher-dependent students, rather than independent, active and self-directed learners. Long and Porter (1985) asserted that the use of group work during class time provides students with increased opportunities to practice the English language and a consequential reduced amount of time allocated to teacher-fronted teaching. Therefore, active group work might serve as a valued teaching tool to provide Saudi students with opportunities to practice English during class time.

The use of group work in classroom contexts does not always contrast traditional classroom instruction (Slavin, 1995). Some effective teaching practices integrate the two strategies; for example, the teacher may introduce and explain the key aspects of a subject matter for one-third of the class time, while the remaining two-thirds are devoted to interactive group work for the students' benefit (Long \& Porter, 1985). For instance, in a grammar lesson about the present continuous tense, a teacher might introduce the tense and explain how it is formed (i.e., subject + helping verb + main verb + ing + complement) in the first third of the class session. In the last two-thirds, the teacher may ask students to work in groups to form new sentences using the present continuous tense structure. This strategy is beneficial as it enables 
a teacher to address and engage in different learning objectives within one class session. Students, likewise, may appreciate the formal teacher instruction, and at the same time are involved in student-to-student interaction to maximise their own learning and construct knowledge.

In a similar vein, cognitive development theorists, notably Piaget (1959) and Vygotsky (1978), have underlined the importance of learners' interaction for cognitive growth, and have therefore provided a theoretical support and rationale for the implementation of group work and active interaction in instructional settings. These theorists' frameworks have offered insight into why students interacting in groups in the classroom setting learn more happily and effectively than those involved in teacher-centred instructions. Central to their theoretical perspectives is the emphasis on the value of social context, and the importance of peer interaction for creating effective learning and cognitive development.

Piaget's (1959) perspective is based on the view that the cognitive disequilibrium that results from social cognitive conflict during peer interactions encourages one's cognitive growth and perspective-taking ability. He argued that, during mutual effort, peers engage in discussion where cognitive disagreement happens and is resolved, while insufficient reasoning is exposed and improved. According to Piaget's theory, the development of culture-arbitrary knowledge including language, morality, and values can be learned only through interacting socially with others. In terms of language teaching, this perception implies the significance of creating an interactive classroom environment such as group work where students engage in authentic situations.

Vygotsky (1978), in turn, based his perspective on the premise that knowledge is social and effective learning takes place in collaborative effort, where participants discuss views and information, and help each other improve. In addition, he proposed the "zone of proximal development" construct, which is based on the contention that interactive activities with adult or more-skilled peer improve learners' cognitive development. As a result, less capable learners can benefit from peer interaction.

The use of group work that involves interactions between learners of English as a foreign language has been supported for two major pedagogical reasons. First, group work increases the number of opportunities for language practice (Long \& Porter, 1985; Ellis, 1999). Effective language learning must comprise sufficient input, intake, and output (Hedge, 2000; McDonough, 2004). Peer interaction in group work can result in more extensive input and language intake than teacher-fronted mode instruction (Long \& Porter, 1985). Group work creates a language acquisition-rich classroom through the authenticity of both language input and output in real situations. The second pedagogical reason is that group work enhances the quality of language learning (Long \& Porter, 1985; Long, 1996). Researchers have argued that interaction in group work draws learners' attention to the language usage in the authentic context of meaning, and drives them to generate more accurate and complex language forms (Gass, 1997; Long \& Porter, 1985; Long, 1996). In addition, learners in group work receive feedback (e.g., on their ungrammatical utterances) from their peers, which enables them to advance their knowledge of the language system (Long, 1996; McDonough, 2004). 
When implementing group work in the classroom environment, it is important to choose the appropriate group size (Blatchford, Kutnick, Baines, \& Galton, 2003; Jacobs, 2006; Johnson \& Johnson, 1994). A large group size might provide students with the opportunity to encounter various perspectives and opinions in relation to experience. Most educators prefer and recommend a group of four (Jacobs, 2006), primarily because of the within-team flexibility a four-member group offers. This flexibility may result in splitting the group into two pairs, switching the group members (i.e., creating a new pair with another teammate), and joining the two pairs with each other (i.e., being squared). It is commonly recommended that a successful group should not include more than four participants; otherwise, the potential advantages in terms of enlarged input may be lost (Blatchford et al., 2003; Jacobs, 2006; Kagan, 1994).

In addition to the appropriate group size, the successful use of group work in the classroom setting entails the appropriate grouping of students with differing levels of abilities in language proficiency (i.e., heterogeneous group; see Blatchford et al., 2003; Johnson, Johnson, \& Holubec, 1998; Slavin, 1995). Heterogeneity among group members creates more opportunities for constructive interaction and allows students to benefit from various skills and perspectives. The use of a heterogeneous group is important; otherwise, students who are unskilled or have minimum learning proficiency may be unlikely to complete activities. In addition, Vygotsky's “zone of proximal development" emphasizes peer scaffolding, in which low achievers can benefit significantly from high achievers. Furthermore, researchers (Johnson et al., 1998; Slavin, 1995) have asserted the idea that students who are high achievers are actually supporting themselves when supporting other students, as the elaboration, reflection, and rehearsal employed in teaching other students might extend their understanding, polish perspectives, and promote communicative skills.

Overall, group work is one of the four proposed indicators of active learning that may have a positive impact on Saudi students' English learning and performance. In teaching practices and/or intervention programs, teachers might group students in classrooms into a four-member, heterogeneous groups (i.e., with differing levels of language proficiency). The implementation of group work in the classroom settings could take the form of activities such as students' discussion of a subject matter, collaboration in doing activities, comparison of answers, and correction of any misconceptions made by group peers. Due to the flexibility of splitting each four-member group into two pairs, in some activities that require a few minutes to complete, teachers may instruct students to work in pairs to maximise their language practice and individual contribution.

\subsection{Elaborated Feedback}

Feedback is one of the most powerful teaching tools that can enhance students' learning and achievement (Hattie \& Timperly, 2007; Hattie \& Gan, 2011; Riviere, 1997). Walberg (1984) ranked feedback as the third most efficient in a list of twenty-six teaching variables that can influence students' performance (Riviere, 1997). Feedback is defined as information provided by an agent (e.g., teacher) concerning aspects of a student's understanding or performance that reduces the discrepancy between what is understood and what is aimed to be understood 
(Hattie \& Timperly, 2007). Feedback, therefore, cannot make an impact in a vacuum; to be effective, it must occur in a learning context (Hattie \& Timperly, 2007).

Feedback is commonly classified into three types (Jaehnig \& Miller, 2007; Wang \& Wu, 2008; Yang \& Wu, 2013). The first type is knowledge of results (KR), which provides students with information about the correctness/incorrectness of their response (e.g., "correct" or "wrong"), without providing the correct answer. The second type is knowledge of correct response (KCR), which informs students of the correct answer and is commonly combined with KR (e.g., "wrong, the correct answer is..."). The third type is elaborated feedback, which provides the correct answer, explains why the answer is correct or incorrect, and involves relevant information (Jaehnig \& Miller, 2007; Wang \& Wu, 2008; Yang \& Wu, 2013).

While feedback has positive effects, not all kinds of feedback are equally efficient. Elaborated feedback, which is the type of feedback emphasized in the present article, has been considered as the most powerful type of feedback (Hattie \& Timperly, 2007; Hattie, 1999; Hattie \& Gan, 2011; Wang \& Wu, 2008). Researchers (e.g., Bangert-Drowns, Kulik, Kulik, \& Morgan, 1991; Barry, 2008; Chang, 2009; Mory, 2004) have argued that feedback involving any kind of elaborated information (e.g., particular hints and guidance on how to improve) is more effective than feedback that notifies students whether their answers are right or wrong. For example, simply telling students which task is correct, which task is incorrect, and which task needs to be redone might not be sufficient information to help students to improve. Elaborated feedback, in contrast, provides students with opportunities to understand why an answer is correct or incorrect and involves possible guidance on coping with difficulties. Such feedback creates a basis for knowledge of how to improve achievement in the future (Hattie \& Timperly, 2007; Saldler, 1998).

Elaborated feedback that involves additional information (e.g., strategic information and cues) might lead to greater opportunities for learning. These learning opportunities might include greater self-regulation over the process of learning, deeper understanding, additional strategies to work on the task, and information about what is and what is not achieved (Hattie \& Timperly, 2007). In addition, elaborated feedback allows students to understand the types of challenges they encounter, and enables teachers to address these challenges (Riviere, 1997).

Experimental studies (e.g., Strijbos, Narciss, \& Dunnebier, 2010; Van der Kleij et al., 2012) have noted that elaborated, specific feedback is more useful than brief, general feedback. In addition, various studies (e.g., Barry, 2008; Straub, 1997) have indicated that students often prefer elaborated and specific feedback and comments that point out their strengths and weaknesses and highlight ways to improve. Furthermore, Nagata (1993) reported, in the domain of second language learning, that feedback that delivered detailed analysis of students' errors was more effective than feedback that addressed only correct and incorrect answers. In a feedback meta-analysis study, Hattie (1999) showed that there is considerable variability in the effects of feedback, and indicated that some types of feedback are more significant than others. He further reported that students provided with information pertaining to a task and how to do it properly showed the highest effect size. Feedback such as praise, punishment, 
and rewards showed the lowest effect size.

Elaborated feedback, if used properly, is a powerful teaching tool. To be most effective, elaborated feedback should to be meaningful, simple, purposeful, clear, and compatible with students' previous performance (Hattie \& Timperly, 2007). Effective elaborated feedback highlights correctness, development, and improvement rather than errors, deficiencies, or total absence of understanding (Hattie \& Timperly, 2007; Riviere, 1997). When providing elaborated feedback, teachers should give suggestions on how to proceed because students may find it difficult to correct their answers or improve their performance when they receive only general feedback (e.g., 'You need to use transition words [e.g., in addition, moreover, for example] to connect your sentences together in the paragraph. Refer to handout number five, which contains examples and explanations on how to use these transition words.'). Furthermore, elaborated feedback needs to be frequent and on a consistent basis (Knox, 1986; Riviere, 1997).

Elaborated feedback complements the use of assessment tasks (e.g., quizzes) and homework to enhance students' understanding (Chang, 2009; Hattie \& Timperly, 2007; Wingate, 2010). Efficient teaching practices involve not only conveying information to students or providing constructive activities, but also using homework and assessments incorporated with feedback to enhance students' understanding of the information and activities. Kilpatrick, Martin, and Schifter (2003) stated that the ideal outcome of students' assessments and homework is for the teacher to gather evidence, make inferences, and then provide feedback to students so that these homework and assessments are used to their maximum effectiveness. In addition, Booth (2010) argued that feedback is essential for students to see the purpose and the worth of the homework and assessment tasks. Elawar and Corno (1985) explored the impact of teachers' written feedback on students' homework. They found that students who received comments and guidance achieved better than those who received grades. The latter resulted in inhibited performance.

Students' homework and assessments, thus, should move beyond the practice usually performed by teachers. In other words, providing students with summative grades without further feedback for completing their assessments and homework does not facilitate students' learning. Chang (2009) indicated that grades, even if they are accompanied with brief positive feedback (e.g., "excellent"), are not adequate to enhance students' performance. Traditionally, and unfortunately, teachers in the Saudi education context frequently grade and record students' homework and assessments without additional feedback upon the completion of these learning duties. Al-Johani (2009) and Khan (2011) stated that students in Saudi English classes are left alone to do or revise their homework without any guidelines from their teachers (Al-Johani, 2009; Khan, 2011). When they try to create drafts, they typically receive consistent criticism regarding their attempts (Al-Johani, 2009).

Overall, elaborated feedback might serve as a powerful tool for enhancing the learning of English in the Saudi Arabian context. In teaching practices and/or educational interventions, teachers need to provide students with timely and consistent elaborated feedback on their homework and assessments tasks (e.g., quizzes). In addition, teachers might use performance 
checklists to identify common issues among students in the classroom activities (e.g., wrong utterance in particular words, lack of helping verb in speaking and writing), homework, and tests. Teachers then provide elaborated feedback on these common issues to students in the classrooms.

\subsection{Situated Learning}

According to Lave and Wenger (e.g., Lave \& Wenger, 1991; Lave, 1988; Wenger, 1998), the theoretical perspective of situated learning emphasizes the nature of learning that highlights the contextualisation of students in specific learning contexts. These contexts and environments are created by students or other individuals (e.g., teachers) with available tools, ideas, and resources (Lave \& Wenger, 1991; Lave, 1988). These contexts present and constrain what students can do and come to know (Sadler, 2009). This theoretical view proposes that learning and knowing cannot be isolated from the contexts in which they take place. Lave and Wenger (1991; Lave, 1988) argued that learning should not be considered as simply the transmission of abstract ideas from one person to another, but a social process in which knowledge is co-constructed. Therefore, they proposed that such learning is situated in particular contexts and embedded within specific social and physical environments. As students participate in these contexts and interact with the communities that form these contexts, they then begin to learn and know (Lave \& Wenger, 1991; Sadler, 2009).

Central to the situated learning perspective is active participation in a community of practice (Lave \& Wenger, 1991; Lave, 1988). Lave and Wenger (1991) defined community of practice as a group of individuals who share a common passion or concern pertaining to something they do, and learn how to improve it better as they regularly interact with each other (e.g., a group of engineers addressing similar challenges). Therefore, a community of practice in the educational context is a process of social learning that happens when students who share a common interest in an area or subject matter (e.g., learning English) collaborate and interact over time, share strategies and ideas, build innovations, and determine solutions to improve their skills in that subject matter. Participants of these communities develop and improve their practices through various learning aspects, involving: solving challenges, seeking the experience of other members, requesting information, discussing developments, experiencing synergy and coordination, recognizing gaps, and mapping knowledge (Lave \& Wenger, 1991; Lave, 1988; Sadler, 2009).

Three main elements are essential when creating communities of practices: the domain, the community, and the practice. The domain is identified and defined by the shared domain of interest (e.g., English learning). Therefore, participants of the community of practice are committed to the domain, and thus have a shared competence that distinguishes them from other people (e.g., a club of friends). The community are the participants who are involved in the shared domain. Therefore, in pursuing the interest of their domain, participants engage in mutual discussions and activities, share information, and assist each other. In addition, they also build relationships that allow them to interact with and learn from each other. The practice or shared practice is defined as what the participants are developing to improve in their shared domain. They develop a shared repertoire of resources that involves, for example, 
useful tools, experiences, stories, and ways of addressing challenges. Consequently, participants need to be practitioners rather than simply a group of people who share an interest in something (Lave \& Wenger, 1991; Lave, 1988; Wenger, 1998). The following paragraphs describe an example of how a situated learning context based on the community of practice might be implemented in the Saudi English classroom setting.

Facebook and situated learning based on the community of practice. Researchers (e.g., Blattner \& Fiori, 2009; Kabilan, Ahmed, Abidin, 2010; Razak, Saeed, \& Ahmed, 2013) have contended that social networking sites (e.g., Facebook, LinkedIn) afford the creation and design of innovative situated learning environments based on the community of practice. They have praised these social networking tools for their abilities to bring individuals together within their platforms and facilitate joint engagement to collaborate, exchange content, acquire knowledge, and develop relationships as a community. In addition, Wellman, Haase, Witte, and Hampton (2001) indicated that joining in virtual communities can amplify the involvement of individuals' face-to-face communities. This observation offers support for the potent social impacts of participation in virtual communities and emphasizes its useful role in an educational environment.

With nearly a billion of active users, Facebook is the fastest and most well-known social networking site worldwide that enables individuals to connect, join groups, and share interests (Espinosa, 2015; Manca \& Ranieri, 2013). Since its inception in 2004, Facebook has been an integral part of high school and tertiary students' daily routine (Blattner \& Fiori, 2009; Espinosa, 2015; Munoz \& Towner, 2009). Wise, Skues, and Williams (2011) indicated that students spend a daily average of one hour on Facebook, especially to socialise with their friends. In addition, Boyd and Ellison (2010) mentioned that students use Facebook to create communities of friends who share mutual characteristics and interests, such as being alumni of a certain college or attending a similar lecture.

Facebook, apart from being one of the most favoured social tools among students and individuals, has received great attention pertaining its role as an educational platform (Aydin, 2012; Munoz \& Towner, 2009; Razak et al., 2013). Facebook has distinctive features that make it amenable for educational uses and pursuits (Munoz \& Towner, 2009). These features include, for example, discussion boards, email, instant messages, chat, and the ability to post and share pictures, videos, comments, and links (Omar, Embi, \& Yunus, 2012). In addition, Facebook allows its users to stay in touch with their friends by facilitating a series of notifications that members receive in their accounts (i.e., profiles). These notifications inform users of, for example, friends' profile changes, new picture posts, new wall postings, and new links to stream videos (Blattner \& Firori, 2009). In addition, Facebook offers its users meaningful interaction synchronously and asynchronously, and direct access to an incredible amount of authentic information on various topics that is available any time and in any place.

Signing up or creating groups is another potential feature that Facebook offers to students or individuals who share similar interests (e.g., study purposes; see Blattner \& Firori, 2009; Razak et al., 2013). All students and teachers can easily sign up for a group (e.g., a classroom group), which can be open to any users or restricted to targeted members. Once students 
become members of a group, they have a variety of possible learning options such as sharing topics, ideas, and views, uploading videos and pictures, and engaging in discussions with the other members of the group. In addition, the group feature keeps its members connected academically via notifications of group postings of any kind (e.g., new video or audio posts; see Blattner \& Firori, 2009). This Facebook group feature provides students as members with attractive opportunities to construct knowledge through interactions between the members of the group, build a learning community, collaborate, learn from each other, and exchange content (Blattner \& Firori, 2009; Razak et al., 2013). Overall, because of these various potential features (e.g., groups, email) embedded in its platform, researchers (Blattner \& Firori, 2009; Munoz \& Towner, 2009; Manca \& Ranieri, 2013) consider Facebook to be more sophisticated than many of its social networking site counterparts, both social (e.g., Twitter, LinkedIn) and academic (e.g., Banner and Blackboard).

In a similar vein, researchers (e.g., Blattner \& Fiori, 2009; Kabilan et al., 2010; Razak et al., 2013; Nikbakht \& Boshrabadi, 2015) have discussed and documented the positive impact of Facebook on students' English learning. Consequently, it seems that Facebook can meet the three fundamental elements of the community of practice in English learning: (i) the domain, (ii) the community, and (iii) the practice. Pertaining to the domain, teachers can create a Facebook group for a specific domain of interest (i.e., English learning), and student members commit to this particular interest by, for example, sharing relevant resources (videos and pictures), engaging in discussions and activities, and posting questions and ideas. The community are the students participating in the Facebook group who are involved in the specific domain of interest (i.e., English learning). The practice entails student members of the Facebook group are practitioners who develop a shared repertoire of resources (e.g., learning materials [e.g., posts and links], experiences, and ways to address learning challenges) to improve in their shared domain (i.e., learning English).

Based on this information, English teachers in Saudi Arabia may use a Facebook group to facilitate a situated learning context based on the community of practice principle (Lave \& Wenger, 1991). Teachers can create a Facebook group called "only for learning English group" for each class. Students in each class might be asked to participate and interact within their Facebook group community at least three times a week (as part of their participation grade). In addition, they need to be instructed to work together, help each other, and share English learning materials such as pictures, videos, and audios. They also need to post comments, questions, ideas, and various topics, reply to their group members' questions, and participate in any other appropriate activities related to their course that could assist them in English learning. Teachers might post announcements, feedback on students' works, discussion topics, and relevant information on learning English. In addition, they need to supervise the groups to ensure that students are interacting and learning.

\subsection{ICT in the Classroom}

The use of Information Communication Technology (ICT) in classroom settings is an effective way to support English teaching and learning. ICT is defined as a set of technological resources and tools (e.g., computers, multimedia, and PowerPoint presentations) 
that are used for communication, creation, dissemination, storage, and management of information (Thierer, 2001). With the availability of these tools and devices (e.g., PowerPoint), teachers have valuable opportunities to design enhanced, interactive lessons (Birch, Sankey, \& Gardiner, 2010). Such technological tools might allow English teachers to create interactive learning materials to support and reinforce a delivered topic, provide students with authentic learning experiences to acquire and master difficult tasks, and present an attractive and rich learning environment. Levert-Duffy, McDonald and Mizell (2005) argued that ICT tools have the potential to meet students' various learning needs, interests, and styles.

PowerPoint presentations are an essential ICT tool that language teachers have commonly used in their teaching. Alkash and Aldersi (2013) stated that PowerPoint has changed the teaching process to be more dynamic with attractive presentations equipped, for example, with videos, pictures, texts, graphs, and tables (see an example of the use of PowerPoint in teaching an English grammar lesson in figure 1 below). Ozaslan and Maden (2013) noted that students learnt better when the learning materials were presented through visualisations (e.g., pictures). The authors further reported that teachers believed that PowerPoint slides help make the material more appealing for students and thereby attract their attention easily. In a similar vein, Corbeil (2007) found that students liked PowerPoint slides for their liveliness, brightness, interactivity, and clarity. He also argued that the tool helps learners to understand better as they can see the example and explanation with visualisations (e.g., videos and pictures). Moreover, the use of visualisations through PowerPoint might make the lesson more engaging and long lasting in the minds of students (Craig \& Amernic, 2006). Furthermore, by using PowerPoint in the classroom, teachers are able to convey more information than through traditional classroom teaching, as the amount of information delivered through traditional teaching is often limited by teachers having to write on the boards.

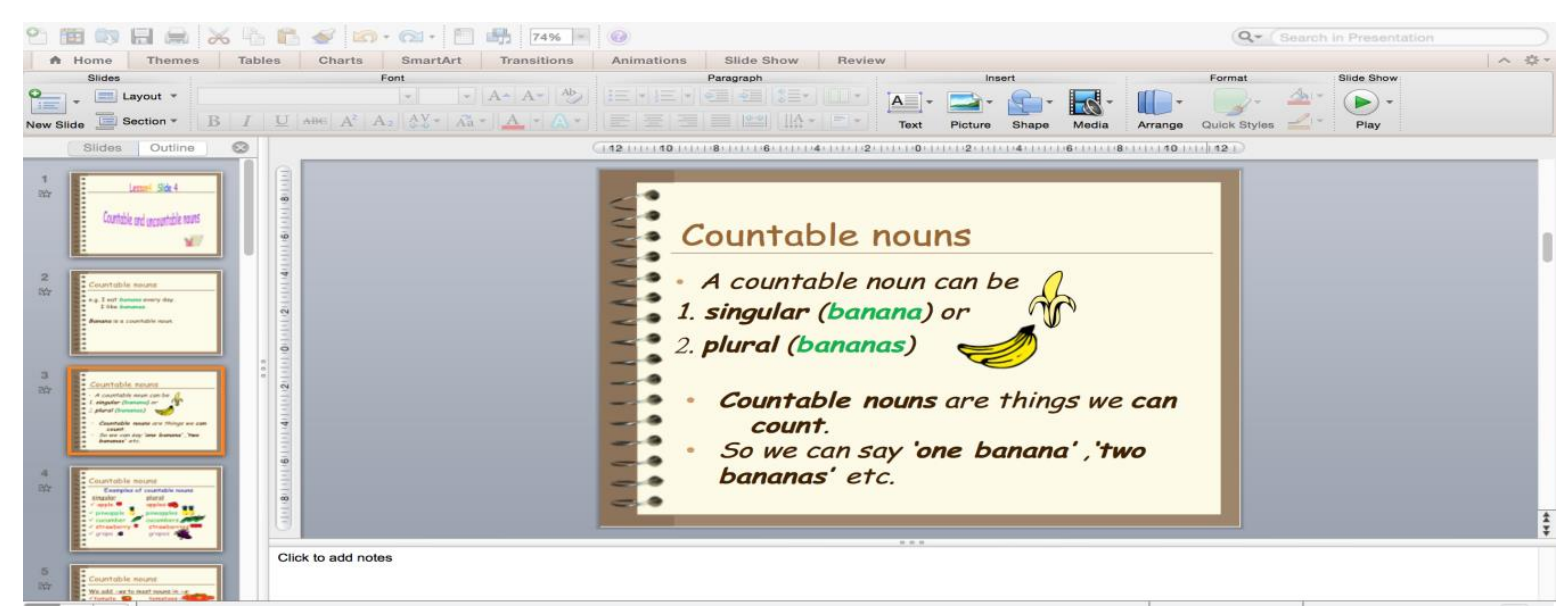

Figure 1. An example of the use of PowerPoint in teaching an English grammar lesson

The use of videos and pictures supported by PowerPoint is an effective way to improve students' English in the classroom environment. Massive numbers of videos (e.g., on 


\section{MInstitute Macrink $_{\text {Insthe }}$}

YouTube and English learning websites) specifically designed for English learning and teaching are available (e.g., https://www.youtube.com/watch?v=ohJCdihPWqc), allowing teachers to choose and download videos according to their students' learning levels and needs. Videos can facilitate the learning process in English classrooms in various ways. For example, videos help make the classroom interesting and less monotonous for students, as well as encouraging students to generate ideas for discussions (Mathew \& Alidmat, 2013). In addition, Cakir (2006) stated that the implementation of videos in English classes ensures authentic language input to students and provides them with opportunities to experience the dynamics of language communication. Furthermore, the use of topic-related videos might help students to contextualise the ideas, and deepen both their thoughts and understanding on that topic (Cakir, 2006).

Apart from videos, the use of various topic-related pictures in the classroom helps make the lesson more interactive and interesting. In addition, with pictures, teachers can introduce and explain a topic both verbally and visually, which might be helpful in attracting students' attention (see an example shown in figure 2 below). Besides, the use of pictures might enhance students' understanding of some language issues/topics that are difficult to be explained verbally. Mayer (2003) argued that teachers' use of a combination of words and pictures can assist students to learn more deeply and faster than from words alone.

In a similar vein, the Dual Coding Theory hypothesized by Paivio $(1971,1986)$ provides a theoretical basis for the use of visualisations (e.g., pictures) in the teaching process. The theory suggests that presenting information in two modalities (i.e., verbal and non-verbal) is essential for learning. The theory assumes that the processing of information involves two cognitive subsystems: (a) a verbal system specialized to deal directly with language (i.e., speeches and written forms), and (b) a non-verbal system specialized to deal with non-linguistic objects and events (e.g., images, emotional responses, action). According to the theory, an individual uses both visual and verbal channels in his processing of information. For example, the eyes receive the visual inputs (e.g., pictures, videos) that enter the cognitive systems as pictorial representations of information, whereas the ears receive the verbal inputs (e.g., spoken words, non-verbal sound cues) that enter the cognitive system as verbal representations of information. Paivio (1986) argued that learning typically occurs more effectively when information is coded dually (verbally and visually) than by visual or verbal coding alone.

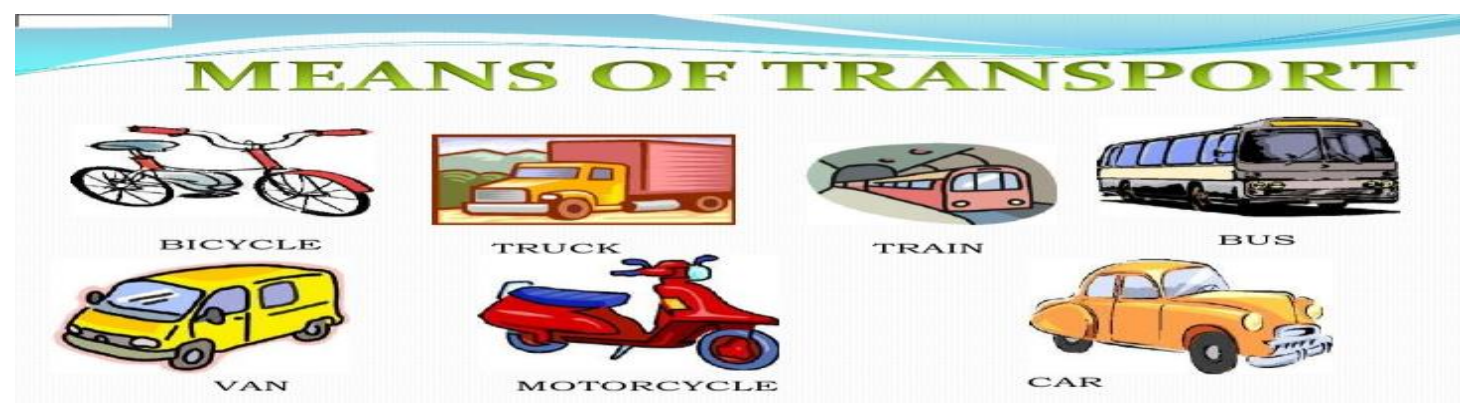

Figure 2. An example of the use of visualisation in teaching an English vocabulary lesson 
Aside from the use of visualisations in the classroom setting, a computer laboratory is an essential part of most educational institutions. Many teachers nowadays use the resources of the computer laboratory to develop their students' English proficiency. Most computer laboratories are equipped with important learning tools such as computers, DVDs, projectors, headsets, and microphones. Okan and Torun (2007) reported that students felt their English language skills improved when they attended the laboratory to visit websites to work on supplementary materials (e.g., grammar points) of their normal class's lessons. They also indicated that students found the computer laboratory made the English course more interesting. In a similar vein, the computer laboratory might allow teachers to provide their students with opportunities to practice various interactive online English learning games/quizzes (e.g., vocabulary synonym match). Khamkhien (2012) argued that computer English learning games offer students a rich and enjoyable learning environment.

Overall, although the adoption of ICT tools in the classroom setting has received considerable attention and become a common practice by teachers in the West, teachers rarely use these technological tools in the Saudi context (Albugarni \& Ahmed, 2015). While the Saudi government has invested significantly in equipping most educational institutions with technologies, barriers including teachers-related factors (e.g., teachers' negative attitudes toward ICT, lack of confidence and competence in using ICT, lack of pedagogical training, and resistance to change) contribute to the low use of ICT in the classroom setting (Albugarni \& Ahmed, 2015; Almalki \& Williams, 2012; Al Mulhim, 2014; Al-Harbi, 2014). Therefore, it is of considerable interest for the current research article to encourage Saudi English teachers to use various ICT tools in the classroom setting to enhance their students' learning and performance.

To conclude, the use of ICT tools can serve as an effective teaching tool to develop Saudi students' English proficiency and achievement in classroom settings. In teaching practices and/or educational interventions, teachers and educators might use PowerPoint slides (incorporated where appropriate with videos, pictures, texts, tables, etc.). These PowerPoint slides may be used in every lesson, for example, to provide a summary of the previous topic, introduce a new topic, and explain the key aspects of the topic. For example, to explain a writing lesson about the outline of a paragraph, teachers can show students a five-minute video on how to write a good outline for a paragraph. In addition, in a grammar lesson, for instance, teachers may show students pictures through PowerPoint to explain the difference between countable and uncountable nouns. Apart from the use of PowerPoint with visualisations in every lesson, students might be given opportunities to visit the computer lab during their study and/or intervention programs. In the computer lab, teachers may provide a list of links of various English learning websites (e.g., BBC learning English, and British Council) for students to browse and elaborate on the topic covered in their normal classes. A secondary benefit is that this exploration familiarises students with these useful websites that may help them during their spare time outside the school/university. Furthermore, teachers might allow students, in groups, to practice learning games, quizzes, and questions on the websites (e.g., questions about the difference between noun and pronoun in a grammar lesson). In addition, teachers need to encourage students to practice these games and quizzes 
at their spare time after school/university hours.

\section{References}

Ahmad, A. M. (2014). Kumaravadivelu's framework as a basis for improving English language teaching in Saudi Arabia: Opportunities and challenges. English Language Teaching, 7(4), 96-110.

Al Mulhim, E. (2014). The barriers to the use of ICT in teaching in Saudi Arabia: A review of literature. Universal Journal of Educational Research, 2(6), 487-493. http://dx.doi.org/10.13189/ ujer.2014.020606

Al-Harbi, H. (2014). Towards successful implementation of ICT in education. Paper presented at the The 2014 WEI International Academic Conference Proceedings.

Al-Johani, H. M. (2009). Finding a way forward the impact of teachers strategies, beliefs and knowledge on teaching English as a foreign language in Saudi Arabia (Unpublished doctoral dissertation). University of Strathclyde, Glasgow, Scotland, UK.

Al-Seghayer, K. (2014). The four most common constraints affecting English teaching in

Saudi Arabia. International Journal of English Linguistics, 4(5), 17. http://dx.doi.org/10.5539/ijel.v4n5p17

Albugarni, S., \& Ahmed, V. (2015). Success factors for ICT implementation in Saudi secondary schools: From the perspective of ICT directors, head teachers, teachers and students. International Journal of Education and Development using Information and Communication Technology, 11(1), $36 . \quad$ Available: http://ijedict.dec.uwi.edu/viewarticle.php?id=1906.

Alhawsawi, S. (2013). Investigating student experiences of learning English as a foreign language in a preparatory programme in a Saudi university (Unpublished doctoral dissertation). University of Sussex, Brighton, UK.

Alkash, K. A. M., \& Al-Dersi, Z. E. M. (2013). Advantages of using PowerPoint presentation in EFL classroom \& the status of its use in Sebha University. International Journal of English Language and Translation Studies, 1(1), 3-16.

Alkubaidi, M. A. (2014). The relationship between Saudi English major university students' writing performance and their learning style and strategy use. English Language Teaching, 7 (4), 83-95. http://dx.doi.org/10.5539/elt.v7n4p83

Almalki, G., \& Williams, N. (2012). A strategy to improve the usage of ICT in the Kingdom of Saudi Arabia primary school. International Journal of Advanced Computer Science \& Application, 3. http://dx.doi.org/10.14569/IJACSA.2012.031007\#.dpuf

Alqahtani, M. (2011). An investigation into the language needs of Saudi students studying in British postgraduate programmes and the cultural differences impacting on them (Unpublished doctoral dissertation). University of Southampton, Southampton, UK.

Alrabai, F. (2014). A model of foreign language anxiety in the Saudi EFL context. English 
Language Teaching,7 (7), 82-101. http://dx.doi.org/10.5539/elt.v7n7p82

Alrashidi, O., \& Phan, H. (2015). Education Context and English Teaching and Learning in the Kingdom of Saudi Arabia: An Overview. English Language Teaching, 8(5), 33. http://dx.doi.org/10.5539/elt.v8n5p33

Aydin, S. (2012). A review of research on Facebook as an educational environment. Educational Technology research and development, 60(6), 1093-1106. http://dx.doi.org/10.1007/s11423-012-9260-7

Bangert-Drowns, R. L., Kulik, C.-L. C., Kulik, J. A., \& Morgan, M. (1991). The instructional effect of feedback in test-like events. Review of Educational Research, 61(2), 213-238.

Barry, V. J. (2008). Using descriptive feedback in a sixth grade mathematics classroom (Doctoral dissertation, University of Nebraska-Lincoln).

Bell, B. S., \& Kozlowski, S. W. (2008). Active learning: effects of core training design elements on self-regulatory processes, learning, and adaptability. Journal of Applied Psychology, 93(2), 296. http://dx.doi.org/10.1037/0021-9010.93.2.296

Birch, D., Sankey, M., \& Gardiner, M. (2010). The impact of multiple representations of content using multimedia on learning outcomes. International Journal of Instructional technology and Distance Learning, $\quad 7(4), \quad 3-19$. http://ijedict.dec.uwi.edu/viewarticle.php?id=1255.

Blatchford, P., Kutnick, P., Baines, E., \& Galton, M. (2003). Toward a social pedagogy of classroom group work. International Journal of Educational Research, 39(1), 153-172. Retrieved from http://search.proquest.com.ezproxy.une.edu.au/docview/62012192?accountid=17227

Blattner, G., \& Fiori, M. (2009). Facebook in the language classroom: Promises and possibilities. International Journal of Instructional Technology and Distance Learning, 6(1), $17-28$.

Bonwell, C. C., \& Eison, J. A. (1991). Active learning: Creating excitement in the classroom. ASHE-ERIC Higher Education Report No. 1. Washington, D.C.: The George Washington University.

Booth, G. I. (2010). The Effects of Homework Assessment on Student Motivation and Achievement (Doctoral dissertation, Central Washington University).

Boyd, D., \& Ellison, N. (2010). Social network sites: definition, history, and scholarship. IEEE Engineering Management Review, 3(38), 16-31. http://dx.doi.org/10.1109/emr.2010.5559139

Braxton, J. M., Milem, J. F., \& Sullivan, A. S. (2000). The influence of active learning on the college student departure process: Toward a revision of Tinto's theory. Journal of higher education, 569-590. http://dx.doi.org/10.2307/2649260

Brown, H. D. (2001). Teaching by principles: An interactive approach to language pedagogy 
(2nd ed.). White Plains, NY: Addison Wesley Longman.

Cakir, I. (2006). The use of video as an audio-visual material in foreign language teaching classroom. TOJET: The Turkish Online Journal of Educational Technology, 5(4), 67-72.

Retrieved

from

http://search.proquest.com.ezproxy.une.edu.au/docview/1288365205?accountid=17227

Chang, N. (2009). Can Students Improve Learning with their use of an Instructor's Extensive Feedback Assessment Process. International Journal of Instructional technology and Distance Learning, 6(5), 49-63.

Chen, R., \& Hird, B. (2006). Group work in the EFL classroom in China: a closer look. RELC Journal, 37(1), 91-103. http://dx.doi.org/10.1177/0033688206063476

Corbeil, G. (2007). Can PowerPoint presentations effectively replace textbooks and blackboards for teaching grammar? Do students find them an effective learning tool? CALICO journal, 631-656.

Craig, R. J., \& Amernic, J. H. (2006). PowerPoint presentation technology and the dynamics of teaching. Innovative Higher Education, 31(3), 147-160. http://dx.doi.org/10.1007/s10755-006-9017-5

Dengler, M. (2008). Classroom active learning complemented by an online discussion forum to teach sustainability. Journal of Geography in Higher Education, 32(3), 481-494. http://dx.doi.org/10.1080/03098260701514108

Elawar, M. C., \& Corno, L. (1985). A factorial experiment in teachers' written feedback on student homework: Changing teacher behavior a little rather than a lot. Journal of Educational Psychology, 77(2), 162. http://dx.doi.org/10.1037/0022-0663.77.2.162

Ellis, R. (1994). The study of second language acquisition. Oxford: Oxford University Press.

Ellis, R. (1999). Learning a second language through interaction. Amsterdam: John Benjamin.

Espinosa, L. F. (2015). The Use of Facebook for Educational Purposes in EFL Classrooms. Theory and Practice in Language Studies, 5(11), 2206. http://dx.doi.org/10.17507/tpls.0511.03

Ewald, J. D. (2004). A classroom forum on small group work: L2 learners see, and change, themselves. $\quad$ Language Awareness, 13(3), 163-179. http://dx.doi.org/10.1080/09658410408667093

Faust, J. L., \& Paulson, D. R. (1998). Active learning in the college classroom. Journal on Excellence in College Teaching, 9(2), 3-24.

Gass, S. (1997). Input, Interaction, and the Second Language Learner. Mahwah, NJ: Lawrence Erlbaum.

Hattie, J. A. (1999). Influences on student learning (Inaugural professorial address, University 
of Auckland, New $\quad$ Zealand). $\quad$ Retrieved from http://www.arts .auckland.ac.nz/staff/index.cfm?P=8650

Hattie, J., \& M. Gan. (2011). Instruction based on feedback. In Handbook of research on learning and instruction, ed. R.E. Mayer and P.A. Alexander, 249-71. New York, NY: Routledge.

Hattie, J., \& Timperley, H. (2007). The power of feedback. Review of Educational Research, 77(1), 81-112. http://dx.doi.org/10.3102/003465430298487

Hedge, T. (2000). Teaching and learning in the language classroom. Oxford: Oxford University Press. http://dx.doi.org/10.5539/elt.v7n4p96

Jacobs, G. M. (2006). Issues in implementing cooperative learning. In S. G. McCafferty, G. M. Jacobs \& A. C. DaSilva Iddings (Eds.), Cooperative learning and second language teaching (pp. 20-46). Cambridge: Cambridge University Press.

Jaehnig, W., \& Miller, M. L. (2007). Feedback types in programmed instruction: A systematic review. The Psychological Record, 57(2), 219.

Johnson, D. W., \& Johnson, R. T. (1994). Learning together. In S. Sharan (Ed.), Handbook of cooperative learning methods (pp. 51-65). Westport, CT: Greenwood Press.

Johnson, D. W., Johnson, R. T., \& Holubec, E. J. (1998). Cooperation in the classroom (7th ed.). Edina, MN: Interaction Book.

Kabilan, M. K., Ahmad, N., \& Abidin, M. J. Z. (2010). Facebook: An online environment for learning of English in institutions of higher education? The Internet and Higher Education, 13(4), 179-187. http://dx.doi.org/10.1016/j.iheduc.2010.07.003

Kagan, S. (1994). Cooperative learning. San Clemente, CA: Kagan Cooperative Learning.

Khamkhien, A. (2012). Computer assisted language learning and English language teaching in Thailand: overview. Mediterranean Journal of Social Sciences, 3(1), 55-64. http://dx.doi.org/10.5901/mjss.2012.03.01.55

Khan, I. (2011). Learning difficulties in English: Diagnosis and pedagogy in Saudi Arabia. Educational Research, 2(7), 1248-1257.

Kilpatrick, J., Martin, G., \& Schifter, D. (Eds.). (2003). A research companion to principals and standards for school mathematics. Reston, VA: National Council of Teachers of Mathematics.

Knox, A. (1986). Helping adults learn. San Francisco, CA: Jossey-Bass, Inc.

Lave, J. (1988). Cognition in practice: Mind, mathematics and culture in everyday life. Boston, MA: Cambridge University Press.

Lave, J., \& Wenger, E. (1991). Situated learning: Legitimate peripheral participation. Cambridge: Cambridge university press. 
Lever-Duffy, J., McDonald, J., \& Mizell, A. (2005). Teaching and learning with technology. New York, NY: Allyn and Bacon.

Long, M. H. (1996). The role of the linguistic environment in second language acquisition. In W. - 206 - C. Ritchie \& T. K. Bhatia (Eds.), Handbook of second language acquisition (pp. 413-468). San Diego: Academic Press.

Long, M. H., \& Porter, P. A. (1985). Group work, interlanguage talk, and second language acquisition. TESOL quarterly, 207-228. http://dx.doi.org/10.2307/3586827

Manca, S., \& Ranieri, M. (2013). Is it a tool suitable for learning? A critical review of the literature on Facebook as a technology - enhanced learning environment. Journal of Computer Assisted Learning, 29(6), 487-504. http://dx.doi.org/10.1111/jcal.12007

Mathew, N. G., \& Alidmat, A. O. H. (2013). A study on the usefulness of audio-visual aids in EFL classroom: Implications for effective instruction.International Journal of Higher Education, 2(2), 86. http://dx.doi.org/10.5430/ijhe.v2n2p86

Mayer, R. E. (2003). Elements of a science of e-learning. Journal of Educational Computing Research, 29(3), 297-313.

McDonough, K. (2004). Learner-learner interaction during pair and small group activities in a Thai EFL context. System, 32(2), 207-224. http://dx.doi.org/10.1016/j.system.2004.01.003

Mory, E. H. (2004). Feedback research review. In D. Jonassen (Ed.), Handbook of research on educational communications and technology (pp. 745-783). Mahwah, NJ: Lawrence Erlbaum.

Munoz, C., \& Towner, T. (2009). Opening Facebook: How to use Facebook in the college classroom. Paper presented at the Society for information technology \& teacher education international conference.

Nagata, N. (1993). Intelligent computer feedback for second language instruction. The Modern Language Journal, 330-339. http://dx.doi.org/10.1111/j.1540-4781.1993.tb01980.x

Naughton, D. (2006). Cooperative strategy training and oral interaction: Enhancing small group communication in the language classroom. Modern Language Journal, 169-184. http://dx.doi.org/10.1111/j.1540-4781.2006.00391.x

Nikbakht, E., \& Boshrabadi, A. M. (2015). Analysing the Potential of Social Networking Sites on EFL Learners' Vocabulary Mastery: A Situated-learning Approach. Theory and Practice in Language Studies, 5(8), 1635. http://dx.doi.org/10.17507/tpls.0508.13

Okan, Z., \& Torun, P. (2007). Learner Attitudes towards CALL Applications at YADIM. Mersin University Journal of the Faculty of Education, 3(2), 162-179.

Omar, H., Embi, M. A., \& Yunus, M. M. (2012). ESL learners' interaction in an online discussion via Facebook. Asian Social Science, $8(11), \quad 67$. http://dx.doi.org/10.5539/ass.v8n11p67 
Ozaslan, E. N., \& Maden, Z. (2013). The use of power point presentations at in the department of foreign language education at middle east. technical university. Middle Eastern \& African Journal of Educational Research, (2).

Paivio, A. (1971). Imagery and verbal processes. New York: Holt, Rinehart, and Winston.

Paivio, A. (1986). Mental representations: a dual coding approach. Oxford. England: Oxford University Press.

Piaget, J. (1959). The language and thought of the child (3rd ed.). London: Routledge \& Kegan-Paul.

Pintrich, P. R., \& Schunk, D. H. (2002). Motivation in education: Theory, research, and applications (2nd ed.). Englewood Cliffs, NJ: Prentice Hall.

Prince, M. (2004). Does active learning work? A review of the research. Journal of engineering education, 223-231. http://dx.doi.org/10.1002/j.2168-9830.2004.tb00809.x

Rajab, H. (2013). Developing speaking and writing skills of L1 Arabic EFL learners through teaching of IPA phonetic codes. Theory and Practice in Language Studies, 3 (4), 653-659. http://dx.doi.org/10.4304/tpls.3.4.653-659

Razak, N. A., Saeed, M., \& Ahmad, Z. (2013). Adopting Social Networking Sites (SNSs) as Interactive Communities among English Foreign Language (EFL) Learners in Writing: Opportunities and Challenges. English Language Teaching, 6(11), 187-198. http://dx.doi.org/10.5539/elt.v6n11p187

Riviere, A. (1997). Feedback: Enhancing the Performance of Adult Learners with Learning Disabilities.

Sadler, D. R. (1998). Formative assessment: Revisiting the territory. Assessment in education, 5(1), 77-84. http://dx.doi.org/10.1080/0969595980050104

Sadler, T. (2009). Situated learning in science education: socio - scientific issues as contexts for practice. Studies in Science Education, 45(1), 1-42. http://dx.doi.org/10.1080/03057260802681839

Sivan, A., Leung, R. W., Woon, C.-c., \& Kember, D. (2000). An implementation of active learning and its effect on the quality of student learning. Innovations in Education and Teaching International, 37(4), 381-389. http://dx.doi.org/10.1080/135580000750052991

Slavin, R. E. (1995). Cooperative learning: Theory, research, and practice (2nd ed.). Needham Heights, MA: Allyn and Bacon.

Straub, R. (1997). Students' reactions to teacher comments: An exploratory study. Research in the Teaching of English, 91-119.

Strijbos, J.-W., Narciss, S., \& Dünnebier, K. (2010). Peer feedback content and sender's competence level in academic writing revision tasks: Are they critical for feedback 
perceptions and efficiency? Learning and Instruction, 20(4), 291-303. http://dx.doi.org/10.1016/j.learninstruc.2009.08.008

Thierer, A. D. (2001). How free computers are filling the "digital divide". Washington, DC: Heritage Foundation.

ur Rahman, M. M., \& Alhaisoni, E. (2013). TEACHING ENGLISH IN SAUDI ARABIA: PROSPECTS AND CHALLENGES. Academic Research International, 4(1), 112-118.

Van der Kleij, F. M., Eggen, T. J., Timmers, C. F., \& Veldkamp, B. P. (2012). Effects of feedback in a computer-based assessment for learning. Computers \& Education, 58(1), 263-272. http://dx.doi.org/10.1016/j.compedu.2011.07.020

Vygotsky, L. S. (1978). Mind in Society: The development of higher psychological processes. M. Cole, V. John-Steiner, S. Scribner, and E. Souberman (Eds.). Cambridge, MA: Harvard University Press.

Walberg, H. J. (1984). Improving the productivity of America's schools. Educational leadership, 41(8), 19-27. http://dx.doi.org/10.17226/9250

Wang, S.-L., \& Wu, P.-Y. (2008). The role of feedback and self-efficacy on web-based learning: The social cognitive perspective. Computers \& Education, 51(4), 1589-1598. http://dx.doi.org/10.1016/j.compedu.2008.03.004

Wellman, B., Haase, A. Q., Witte, J., \& Hampton, K. (2001). Does the Internet increase, decrease, or supplement social capital? Social networks, participation, and community commitment. American behavioral scientist, 45(3), 436-455. http://dx.doi.org/10.1177/00027640121957286

Wenger, E. (1998). Communities of practice. New York: Cambridge University Press.

Wingate, U. (2010). The impact of formative feedback on the development of academic writing. Assessment \& Evaluation in Higher Education, 35(5), 519-533. http://dx.doi.org/10.1080/02602930903512909

Wise, L., Skues, J., \& Williams, B. (2011). Facebook in higher education promotes social but not academic engagement. Changing demands, changing directions. Proceedings ascilite Hobart, 1332-1342.

Yang, K.-H., \& Wu, Y.-H. (2013). Effects of Feedback Types on the Student's Self-Efficacy. International Journal of e-Education, e-Business, e-Management and e-Learning, 3(3), 202. http://dx.doi.org/10.7763/ijeeee.2013.v3.223

\section{Copyright Disclaimer}

Copyright for this article is retained by the author(s), with first publication rights granted to the journal.

This is an open-access article distributed under the terms and conditions of the Creative Commons Attribution license (http://creativecommons.org/licenses/by/3.0/). 